\title{
The Effects of Financial Literacy on Sustainable Entrepreneurship
}

\author{
Alberto Burchi ${ }^{1, *}$, Bogdan Włodarczyk ${ }^{2} \mathbb{D}$, Marek Szturo $^{2} \mathbb{D}$ and Duccio Martelli ${ }^{1}$ \\ 1 Department of Economics, University of Perugia, 06123 Perugia, Italy; duccio.martelli@unipg.it \\ 2 Department of Finance, Faculty of Economic Sciences, University of Warmia and Mazury, \\ 10-720 Olsztyn, Poland; bogdan.wlodarczyk@uwm.edu.pl (B.W.); marsz@uwm.edu.pl (M.S.) \\ * Correspondence: alberto.burchi@unipg.it; Tel.: +39-075-585-5247
}

Citation: Burchi, A.; Włodarczyk, B.; Szturo, M.; Martelli, D. The Effects of Financial Literacy on Sustainable Entrepreneurship. Sustainability 2021, 13, 5070. https://doi.org/10.3390/ su13095070

\section{Academic Editors:}

Ştefan Cristian Gherghina

and Adam P. Balcerzak

Received: 18 March 2021

Accepted: 26 April 2021

Published: 30 April 2021

Publisher's Note: MDPI stays neutral with regard to jurisdictional claims in published maps and institutional affiliations.

Copyright: (c) 2021 by the authors. Licensee MDPI, Basel, Switzerland. This article is an open access article distributed under the terms and conditions of the Creative Commons Attribution (CC BY) license (https:// creativecommons.org/licenses/by/ $4.0 /)$.

\begin{abstract}
Entrepreneurship contributes to the economic well-being of every country. Specifically, the level of individual entrepreneurship is crucial in the process of developing and building economic potential, especially in Central European countries. Among the several factors impacting entrepreneurship, the ability to access the necessary external sources of financing need to be considered crucial. The financial literacy of the entrepreneur plays a crucial role in the relationship between the lender and the borrower. In this paper, we investigate the effects of financial literacy on sustainable entrepreneurship. We based our analysis on the framework proposed by the World Economic Forum. We present an OLS model that adopts entrepreneurship, financial literacy and macroeconomic variables. The analysis is carried out on individual and national data from different sources of information (Global Entrepreneurship Monitor, World Bank, and Organization for Economic Co-operation and Development). The results show a positive and statistically significant relationship between financial literacy and sustainable entrepreneurial activity. This evidence supports the increasing number of financial education initiatives and the inclusion of topics related to economic and financial culture in school education systems. We identify internationally valid policy implications. In the context of the growth strategies of Central European countries, financial literacy takes on even greater importance. The introduction of financial education in the national curricula could strengthen entrepreneurial skills and accelerate the inclusive growth process across Europe.
\end{abstract}

Keywords: sustainable entrepreneurship; financial literacy; MSMEs

\section{Introduction}

Entrepreneurship is considered a driver of economic development, as Schumpeter suggested when he proposed the concept of "creative destruction", with reference to the impacts that new inventions generally have on the economy [1]. However, it was only over the last two decades that scholars in economics have started to systematically propose methodological frameworks to analyze entrepreneurship (see Shane and Venkataraman [2]) or to investigate the intersections between it and economic development (among the others, see Acs, Desai and Hessel [3]). Naudé [4] suggests that studies on entrepreneurship and its relation to economic development can be grouped into at least four themes, such as defining the nature of economic development and its relationship with various concepts of entrepreneurship; measuring entrepreneurship and the business environment and adopting new indices of entrepreneurial development, due to the increasing availability of data; estimating the relationship between measures of entrepreneurship and measures of economic development; and finally, studying the relationship between the state and entrepreneurs.

Scholars in entrepreneurship often highlight firm-level outcomes: economic growth and business performance [5]. The debate on the relationship between economic growth, well-being and methods of measurement is still ongoing. More recently, however, scholars have pointed out the positive effect between entrepreneurial initiative and social wellbeing [6]. Entrepreneurship boosts economic growth through many direct and indirect 
positive effects: it contributes to social development [7], has positive effects on innovation [8], introduces new technologies [9] and encourages the creation of new business opportunities [10]. Entrepreneurship has the more positive effects the more the economy has unexplored potential. In less developed countries, enhancement of entrepreneurship leads to economic development [11]. For instance, during the past 25 years, entrepreneurs in Central and Eastern Europe have reshaped local economies, applying innovative ideas to traditional industries. As far as the strengths and weaknesses of MSMEs in Poland, which represents the most important Eastern European country, in 2004, at the time the country entered the EU market, the points of weakness outnumbered the strengths. According to Piasecki and Rogut [12] the Polish economic system was characterized, among the others, by poor financial liquidity, a low investment activity, outdated technology and a low level of innovation. The weak points summarized above were not confined to Poland, but were popular in many other new member states of the EU that were operating under central planning and the socialist model of development.

The phenomenon of entrepreneurship can only be fully understood by taking into account its regional nature $[13,14]$. The special issue to which this work wants to contribute starts with the relevance of local conditions as a key to the analysis of entrepreneurship. The variables that help to understand the environment in which entrepreneurship develops are: institutions, networks, regional policies, the educational system, social culture and knowledge of agents. In this work, we focus on the knowledge necessary for entrepreneurial activity. Specifically, on financial knowledge.

The entrepreneurial phenomenon is very heterogeneous. Scholars have repeatedly attempted to find a univocal definition, with the aim of identifying the boundaries of a research field of such interest [15], and to study the effects of entrepreneurship on the economy [16-19]. Scientific production in this area is of great quality and elegance. However, over the years, there has not been a parallel development of empirical analyzes, due to the difficulty of defining the role of entrepreneurship and of formalizing its measure for quantitative modeling [20]. In recent years, taking into consideration the positive effects associated with a healthy entrepreneurial activity, researchers have extensively investigated how factors, such as tax policy, government subsidies, intellectual property protection, various legal processes, civil society structure and economic conditions affect the business activity or company growth [21-23].

Currently, scholars and entrepreneurs do not look at entrepreneurship as a vehicle to solve problems only related to financial and economic terms; entrepreneurship also plays a crucial role in social and sustainable development, thanks to the presence of institutions, which positively affect the entrepreneurial activity in different ways (see Aparicio, Turro and Noguera et al. [24] for a detailed discussion). The authors propose a new framework, showing the impacts that formal and informal institutions have on the formation and the development of entrepreneurial activities and its diversity, and the development outcomes (economic, social change and sustainability) that entrepreneurship can achieve.

Furthermore, Gast et al. [25] developed an integrative conceptual model for ecologically sustainable entrepreneurship, which can be applied by both new firms and SMEs. Conducting business in a greener and more sustainable way has become an important element of all entrepreneurial activities. A central factor in the proposed framework is the role of education, which can encourage participants to consider more ecological and sustainable approaches to entrepreneurship.

A growing debate about sustainable entrepreneurship refers to the question of whether green growth can be achieved without harming economic growth. Very recently, Fernandes et al. [26] tried to answer this key question, analyzing the roles that sustainable technology transfer and sustainable innovations play in green growth and ascertain the impact of green growth on economic growth.

Despite that there is no final answer yet, their results confirm that sustainable technology transfer and sustainable innovation have an impact on green growth, and that green 
growth has a positive impact on economic growth and mediates the positive effect between sustainable technology transfer and sustainable innovation and economic growth.

Given the importance of entrepreneurship to ensure sustainable development, policymakers from all over the world have taken steps to create favorable conditions. To create public policies, laws and initiatives more general, to guide the action of the policymaker, it is necessary to know the phenomenon, its characteristics and how agents respond to changes in the system in which they act. The above considerations lead to the need for scholars to investigate the phenomenon of entrepreneurship and to provide the policymakers with the necessary indications for designing a more effective framework, encouraging more entrepreneurial initiatives.

There are many elements necessary to support the development of entrepreneurial actions. Among others, the access to sources of financing in an efficient manner is essential [27-29]. A vast amount of literature has documented that the ability to access the necessary external funding is a catalyst for entrepreneurship [30,31]. The ability to access different sources of funding depends on additional factors. On the supply side, being able to raise funds in efficient markets, or borrowing money from efficient intermediaries and banks, in particular, represents basic conditions for collecting money in convenient conditions. The demand side is instead interpreted as a given. In other words, the ability of the whole economic system to obtain the necessary financing is often considered a given element, related to the structure of the country's economic and financial system. These aspects have an influence on the risk, and therefore on the pricing, of each transaction, but not in the access to the various financing alternatives. In this framework, the understanding of the entrepreneur is crucial [32]. Financial literacy plays a central role in the relationship between entrepreneur, financial markets and intermediaries, and potential lenders in general. Scientific research has highlighted the relationship between financial literacy and financial behavior [33]. Financial literacy is a resource that allows the relationship between market agents to improve, as it mitigates the information asymmetry between lenders and borrowers [34]. In other words, financial literacy does not have to be considered just an incentive factor; it is an essential element for developing a sustainable entrepreneurship.

This work aims to provide new empirical evidence regarding the effects of financial literacy on sustainable entrepreneurship. The research question is whether a higher level of financial literacy among citizens leads to greater sustainable entrepreneurship in the country.

The analysis is carried out on individual and national data from different sources of information: Global Entrepreneurship Monitor (GEM), World Bank (WB), and Organization for Economic Co-operation and Development (OECD). Results show a positive and statistically significant relationship between financial literacy and entrepreneurial activity. The findings of this study support the provision of financial literacy in schools and educational projects aimed at educating current and aspiring entrepreneurs.

The present study contributes to the existing literature, because to our knowledge, it is one of the very first research to investigate the impacts of financial literacy on entrepreneurship combining data from different datasets and sources. Our work is inspired by the works of Anton and Bostan [27], and Rusu and Roman [35]. Our incremental contribution lies in taking into account the effects of financial literacy on entrepreneurship. We shed new light on the link between financial knowledge and the decision to take the entrepreneurial path.

The rest of the paper is divided as follows: Section 2 summarizes the relevant review of the literature; Section 3 shows the methodology and data analyzed in the paper; Section 4 presents and discusses the results of the study; Section 5 presents some robustness checks and shows the limits of the work; finally, Section 6 highlights future research developments.

\section{Literature Review}

There is no general agreement on what the term entrepreneurship means, and on the several methodologies present in the literature to investigate such phenomenon. In this study, we adopt the theoretical model proposed by GEM and briefly described it below. 
The GEM report, introduced in 1999, allows us to identify a variable, which is widely used to determine the value of entrepreneurial initiatives: the Total Entrepreneurship Activity (TEA) [36]. The TEA rate measures the proportion of working-age adults in the population who are either involved in the process of starting up a business (prospective entrepreneur) or are active as owners/managers of enterprises. This measure includes both the broader definition of Schumpeterian entrepreneur [37], as well as managerial business owners.

Wong, Ho, and Autio [20] adopted the TEA measures and the different variations that diversify the cognitive objective to study four different types of entrepreneurial activities: high growth potential TEA, necessity TEA, opportunity TEA and overall TEA. Of the four types of entrepreneurship, only high growth potential entrepreneurship is found to have a significant impact on economic growth.

Many of the previous analyses, using GEM individual data, deal with specific countries, e.g., [38] for Germany, whereas others focus on wider geographical regions using aggregated data [39].

The variables that influence entrepreneurial activity are numerous. There are many attempts to analyze the characteristics favorable to the entrepreneurial initiative. In the literature, these factors are usually divided into three categories $[8,10]$ : economic factors [40], socio-cultural factors [41] and determinants of perception [42,43]. In fact, Shane and Venkataraman [2] point out that analyzing the process of starting a new business should consider the individual and the opportunity. Regarding economic factors, the literature has extensively analyzed the positive effects of entrepreneurship on the economic growth of the countries [44]. Additionally, a favorable and stable economic system helps to create the conditions for a new business, facilitates the perception of opportunities and allows agents to operate with confidence [8].

Regarding socio-cultural factors, high levels of economic culture can stimulate entrepreneurship. The role played by the education system is essential here. Identifying the necessary skills and encouraging coherent education and training actions leads to an increase in entrepreneurship [45].

Micro, small and medium-sized enterprises (MSMEs) represent the large majority of firms worldwide, fostering the growth and the development of sustainable economic systems, and increasing the financial stability of every country [46]. The long-term development and growth of MSMEs depend on a variety of different factors both related to the demand and the supply side; in recent years, one of the key drivers impacting the success of the firms, a factor that in the past has always been underestimated, is the level of financial literacy of entrepreneurs, as the OECD, in particular, has mentioned in several papers [47-49]. In the literature, the first noteworthy study on this subject is by Karlan and Valdivia in 2011 [50]: the authors show the positive impacts of teaching even basic financial concepts to micro-business entrepreneurs. Further studies on the relationship between financial education and entrepreneurship in MSMEs reveal how, although the level of financial literacy varies depending on the firm's size, these enterprises require a wider range of business and financial skills (both at a generic and at a more specific level), including, among others, knowledge about financial management, negotiation, human resources and public relations, especially towards the several types of stakeholders the firm has to deal with (e.g., employees, clients, local communities). All of these skills represent crucial characteristics that the entrepreneur has to own, to let the firm be successful in the long term, especially in competitive and volatile environments, as is the current scenario.

This paper is part of the strand of literature analyzing the several different skills an entrepreneur should own to successfully manage a firm. In particular, we based our analysis on the framework proposed by the World Economic Forum [51], which defines entrepreneurship education as the sum of three main components, such as personal development, business development and entrepreneurial skill development. Among these three categories, we focus our attention on a very specific element included in the second area (i.e., business development), such as financial literacy. Although there is no general agreement about the definition, according to a more comprehensive definition 
proposed by OECD in 2018 [52], financial literacy can be described as "a combination of awareness, knowledge, skill, attitude and behavior necessary to make sound financial decisions and ultimately achieve individual financial wellbeing." With regards to entrepreneurs more specifically, financial literacy refers to financial skills that allow a firm to adopt more effective financial management decisions, to increase the firm's profitability and to adopt sustainable long-term growth strategies of the business [53].

Research conducted by several scholars tend to confirm a direct relationship between the level of financial literacy of entrepreneurs and the performance of their firms $[54,55]$. Other studies show indirect relationships between these two variables, as a result of the entrepreneurs' financial skills and knowledge, which positively affect other performance drivers, such as the ability to access different sources of funding at better conditions [56] or to be able to use innovative financial services, which allow the firm to exploit growth opportunities offered by financial markets [57]. Finally, financial literacy was also related to indebtedness and the type of investments that firms tend to prefer [58].

According to a recent survey concerning the top 20 reasons why startups fail [59], $29 \%$ of the new ventures investigated fail because they run out of money. Being financially educated makes entrepreneurs more likely to make more sound investment and financing decisions. Wise [60] supports this evidence, showing that increases in financial literacy lead entrepreneurs to have a higher probability of loan repayment and a lower probability to close their venture involuntarily. Although several empirical studies show the many benefits of financial literacy to entrepreneurship, financial education has never been considered a real subject in the development of the core curriculum of any student, who represents a hypothetical entrepreneur tomorrow. Unfortunately, during the years of study, young adults do not acquire sufficient financial knowledge and skills to be able to make sound saving or investment decisions, either personal or in the firm's domain [61]. This scenario incentives students to apply for a job in a company in exchange for a regular salary, rather than to realize their own business ideas. In fact, studies on this topic show that as the financial literacy increases, so does the number of people who start some kind of entrepreneurial initiatives [62], taking the advantage of the many options that financial markets offer nowadays to finance business projects, even though they are only ideas [63]. With this in mind, financial literacy affects not only risk appetite (in this case business risk) but also encourages entrepreneurs to constantly look for changes, pushing them to always own the right skills to achieve in any kind of business environment. In line with what is already present in the literature, entrepreneurial activity is part of a broader ecosystem, where individual agents do not behave independently from the other ones, but they are interconnected. From this perspective, the success of a business initiative is thus not defined only by its economic results, but more generally it is evaluated according to the value generated for the firm and its stakeholders. For a more in-depth analysis on this subject, see Abad-Segura et al. [64].

Financial literacy thus represents a resource available to MSMEs for the creation of firm value, leading them to more sustainable results in the long term [65]. In fact, the financial literacy of the entrepreneur guarantees greater flexibility to the firm, and consequently, a better ability to adapt to new market conditions, leading the firm to higher and more sustainable results in the long term [66], as also demonstrated by research that positively correlates the financial literacy of the entrepreneur to the firm's performance (among others [67]). Some studies show, for example, how financial literacy is important for the survival of MSMEs, as low levels of financial knowledge can lead the entrepreneur to make many mistakes [60]. It should therefore not be surprising that financial literacy is becoming one of the most relevant factors in the firm's decision-making process [68]: financially educated entrepreneurs are able to implement financial and economic best practices, which is an incentive to more sustainable growth. These results are also confirmed by recent analyses [69], showing how financial literacy directly affects the sustainability of MSMEs, while other variables, such as the access to credit and the firm's risk attitude, act as mediators of this relationship. 
The study is motivated by the aim to determine whether there is a relationship between financial literacy and entrepreneurship. In particular, since financial literacy is a combination of many different aspects, as the OECD suggests, we prefer to split financial literacy into two basic main components: the first one related to elementary financial knowledge, such as inflation and interest rates; the second one including the ability to calculate the compounded capitalization as well, so to be able to distinguish between more or less financially educated entrepreneurs.

The following two research hypotheses are thus investigated:

RH1: Is there a positive relationship between financial literacy and entrepreneurship?

RH2: Are more educated entrepreneurs able to generate more business?

We expect that not only is there a positive relationship between financial literacy and entrepreneurship but also that educated entrepreneurs are more able to generate business.

\section{Methodology}

The objective of our analysis focused on studying the role of the population's financial literacy on entrepreneurship. In order to measure the effects of financial knowledge on the likelihood to engage in entrepreneurial activity, we need to properly estimate the phenomena under analysis. We collected information from various data sources; specifically from Organization for Economic Cooperation and Development (OECD) for financial literacy, from Global Entrepreneurship Monitor (GEM) for entrepreneurship and, finally, from World Bank (WB) for macroeconomic data. Our analysis combines individual level entrepreneurship with macroeconomic data from 30 countries.

In 2002, OECD governments recognized the importance of financial literacy and launched an ambitious project. In 2008, the project received a significant acceleration, thanks to the creation of the International Network on Financial Education (OECD/INFE). The aims of the project were the development of four key policy areas related to financial literacy: (i) Setting standards, implementation and evaluation; (ii) Financial education and the impact of digitalization; (iii) Financial education in the workplace; (iv) The impact of ageing populations and the needs of older consumers [70]. One of the most successful areas of the OECD/INFE was to undertake a large-scale financial literacy survey process. In 2016, an analysis was conducted in G20 countries. Using the toolkit to measure financial literacy and financial inclusion developed by the OECD/INFE, the report "International Survey of Adult Financial Literacy" [71] was released. The report represented a milestone in the attempt to measure worldwide the financial literacy of citizens across different countries. The survey results were released at the Global Symposium on Financial Education in Auckland, New Zealand, on 12 October 2016. A total of 51,650 adults aged 18 to 79 from 30 countries and economies participated in the survey. Based on this same methodology, a separate report, specific for the G20 countries only, was prepared and released in 2017 under the German G20 presidency [72]. Given the difficulty in organizing such an extensive survey, the OECD reports, as well as other experiments in the measurement of financial literacy, are not always very regular and time intervals between the two analyses could even be years.

The countries that participated in both surveys (2016 and 2017) are part of our sample. We delete from the sample the double observations and those relating to countries where data on entrepreneurship are not available. The final sample consists of 30 countries (Table 1 ).

Regarding entrepreneurship data, we adopted the GEM database (Adult Population Survey-APS). Since 1999, GEM has cumulatively surveyed over 3 million adults in 114 economies across the globe. The APS asks national representative samples of at least 2000 working-age adults (18-64 year), about their entrepreneurial activities, attitudes, motivations and ambitions, using the standards of the GEM questionnaire. Results are then cross-checked and quality-approved by GEM's technical team [73]. Macroeconomic data come from the World Bank (Doing Business and World Development Indicators). Data on Global Competitiveness Index (GCI) retrieved from World Economic Forum. Data on 
corruption and political stability are obtained from World Bank's Worldwide Governance Indicator Project.

Table 1. Countries in the sample.

\begin{tabular}{ccc}
\hline Argentina & Germany & Mexico \\
Austria & Hong Kong & Netherlands \\
Brazil & Hungary & Poland \\
Canada & India & Portugal \\
China & Indonesia & Russia \\
Croatia & Italy & Saudi Arabia \\
Estonia & Jordan & South Africa \\
Finland & Korea & Thailand \\
France & Latvia & Turkey \\
Georgia & Malaysia & United Kingdom \\
\hline
\end{tabular}

The 2016 GEM survey is currently the most recent available. In fact, the full datasets are only freely available to the public three years after the data collection. Indeed, the recent release of 2016 data by the GEM makes it possible to compare the data on financial literacy collected by OECD in the same period. Table 2 shows the detailed description of the variables and specifies their source. In order to choose the macroeconomic variables and those relating to entrepreneurship, we partially followed the work of Anton and Bostan [27]. Where possible, for all the variables, we adopted the same acronyms created by those who took care of the survey (More information on the survey method and the statistical methodology adopted by GEM can be found in https: / /www.gemconsortium. org/about/wiki (last access: 21 April 2021). Information on the methodology adopted by the Word Bank to estimate the scores can be collected at the following link: https: //www.doingbusiness.org/en/methodology (last access: 21 April 2021).

Table 2. Variables employed in the analysis.

\begin{tabular}{|c|c|c|}
\hline Name & Definition & Source \\
\hline $\begin{array}{l}\text { The total early-stage } \\
\text { entrepreneurial activity rate (TEA) }\end{array}$ & $\begin{array}{l}\text { The percentage of the } 18-64 \text { population who are } \\
\text { either a nascent entrepreneur or owner-manager of } \\
\text { a new business. }\end{array}$ & Global Entrepreneurship Monitor \\
\hline $\begin{array}{l}\text { Nascent Entrepreneurship Rate } \\
\text { (SUBOAN) }\end{array}$ & $\begin{array}{l}\text { The percentage of the } 18-64 \text { population who are } \\
\text { currently a nascent entrepreneur. They are actively } \\
\text { engaged in creating a business or are the owners of } \\
\text { it. This new business venture has not yet paid wages } \\
\text { or other types of payments in the past three months. }\end{array}$ & Global Entrepreneurship Monitor \\
\hline $\begin{array}{c}\text { New Business Ownership Rate } \\
\text { (BABYBU) }\end{array}$ & $\begin{array}{l}\text { The percentage of } 18-64 \text { population who are } \\
\text { currently an owner/manager of a new business. } \\
\text { They are the owners of a new business. This new } \\
\text { business venture has already paid wages or other } \\
\text { types of payments but that money flow started no } \\
\text { more than } 3.5 \text { years ago. }\end{array}$ & Global Entrepreneurship Monitor \\
\hline Informal Investors Rate (BUSANG) & $\begin{array}{l}\text { The percentage of } 18-64 \text { population who have } \\
\text { personally provided funds for a new business, } \\
\text { started by someone else, in the past three years, } \\
\text { excluding stocks and funds. }\end{array}$ & Global Entrepreneurship Monitor \\
\hline
\end{tabular}


Table 2. Cont.

\begin{tabular}{llc}
\hline Name & Definition & Source \\
\hline
\end{tabular}

The total score for getting credit is the sum of the strength of legal rights index and the depth of credit information index. The first measure is based on the effectiveness of applicable laws on guarantees and bankruptcies. The second measure evaluates the

Getting Credit total score (GETCRED)

Cost (\% of claim) (ENCO)

Fear of Failure Rate (FRFAIL)

Perceived to have required knowledge and skills (SUSKIL)

Personal contact with someone who has started a new business. (KNOENT)

GDP per capita growth (GDPCG)

Corruption (CORRUP)

Global Competitiveness Index (GCI) accessibility of credit information available through credit reporting service providers such as credit bureaus or credit registers. https: / / www.doingbus iness.org/en/methodology/getting-credit (last access: 21 April 2021).

The cost to enforce contracts is recorded as a percentage of the claim value, assumed to be equivalent to $200 \%$ of income per capita or $\$ 5000$, whichever is greater. Three types of costs are recorded: average attorney fees, court costs and enforcement costs. Bribes are not taken into account. Average legal fees are the expenses that the seller (plaintiff) must advance to a local lawyer to represent. Court costs include all costs that the seller (plaintiff) must advance to the court. Enforcement costs are all costs that the seller (plaintiff) has to anticipate to enforce the judgment through a public sale of the buyer's assets. https: / / www.doingbusin ess.org/en/methodology/enforcing-contracts (last access: 21 April 2021).

The percentage of the 18-64 population who agree that they see good opportunities but would not start a business for fear it might fail.

The Percentage of 18-64 population who perceive to have the required knowledge and skills to start a business.

The Percentage of 18-64 population who personally knows someone who started a firm in the past two years.

Annual percentage growth rate of GDP per capita based on constant local currency.

Perceptions of the extent to which public power is exercised for private gain. https:/ / tcdata360.worldb ank.org / indicators / hc153e067? country=BRA\&ind icator=364\&viz=line_chart\&years=1996, 2019

(last access: 21 April 2021).

The index measures different aspects of the competitiveness of a country. Competitiveness is defined as "the set of institutions, policies, and factors that determine the level of productivity of a country". https: //tcdata360.worldbank.org/indicators/gci?country $=$ BRA\&indicator $=631 \&$ viz $=$ line_chart $\&$ years $=2007$, 2017 (last access: 21 April 2021).
World Bank, Doing Business

World Bank, Doing Business

Global Entrepreneurship Monitor

Global Entrepreneurship Monitor

Global Entrepreneurship Monitor

World Bank,

World Development Indicators

World Bank, Worldwide Governance Indicator Project

World Economic Forum 
Table 2. Cont.

\begin{tabular}{|c|c|c|}
\hline Name & Definition & Source \\
\hline Political stability (POL) & $\begin{array}{l}\text { Pol measures perceptions of the likelihood of } \\
\text { political instability and/or politically-motivated } \\
\text { violence, including terrorism. The value of this index } \\
\text { ranged from approximately }-2.5 \text { (political } \\
\text { instability) to } 2.5 \text { (political stability). } \\
\text { https:/ / datacatalog.worldbank.org/political-stabil } \\
\text { ity-and-absence-violenceterrorism-estimate } \\
\text { (last access: } 21 \text { April 2021). }\end{array}$ & $\begin{array}{c}\text { World Bank, Worldwide } \\
\text { Governance Indicator Project }\end{array}$ \\
\hline QK3 & $\begin{array}{c}\text { Percentage of the population that answered question } \\
3 \text { correctly in the financial literacy } \\
\text { measurement exercise. }\end{array}$ & OECD/INFE \\
\hline QK4 & $\begin{array}{c}\text { Percentage of the population that answered question } \\
4 \text { correctly in the financial literacy } \\
\text { measurement exercise. }\end{array}$ & OECD/INFE \\
\hline QK5 & $\begin{array}{c}\text { Percentage of the population that answered question } \\
5 \text { correctly in the financial literacy } \\
\text { measurement exercise. }\end{array}$ & OECD/INFE \\
\hline FINLIT1 & Sum of variables QK3 and QK4 & OECD/INFE \\
\hline FINLIT2 & Sum of variables QK3, QK4 and QK5 & OECD/INFE \\
\hline
\end{tabular}

As an index of entrepreneurship, we have adopted the total early-stage entrepreneurial activity rate (TEA). TEA is the GEM's most well-known index. TEA rate is calculated as the percentage of the adult population aged 18-64 years who are in the process of starting a business (a nascent entrepreneur-SUBOAN) or started a business less than 42 months old before the survey took place (owner/manager of a new business-BABYBU). In order to better understand the phenomenon, we also analyzed the sub-indices developed by GEM to measure the two components of the entrepreneurial phenomenon: nascent entrepreneur (SUBOAN) and owner/manager in a new firm (BABYBU). These variables are adopted as dependent variables of our analysis model.

To measure the ease of obtaining financing to start your own entrepreneurial enterprise, we have adopted some variables. The percentage of the 18-64 population who have personally provided funds for a new business, started by someone else, in the past three years, excluding stocks and funds (BUSANG).

The Getting Credit total score (GETCRED) indicator is developed by the World Bank, Doing Business project. The variable measures two aspects of access to financing: the strength of credit reporting systems and the effectiveness of collateral and bankruptcy laws. These variables are essential in facilitating lending. Indeed, the inability of lenders to accurately assess the creditworthiness of borrowers contributes to higher default rates. Lenders are also unwilling to provide credit if there is no guarantee that they will be able to enforce their bankruptcy rights through a timely and inexpensive process. Therefore, both characteristics are essential in measuring the efficiency of the credit system.

The cost to enforce contracts is recorded as a percentage of the claim value, assumed equivalent to $200 \%$ of income per capita or $\$ 5000$, whichever is greater (ENCO). The reliability of the legal system and contracts, in particular, is essential for economic development and sustained growth. A rule of law that ensures excellent protection of rights requires an efficient legal system for the administration of justice. The solution to legal disputes must be fast, certain and cheap. Economies with a judicial system capable of ensuring the certainty of legal considerations are able to attract capital from the outside and encourage entrepreneurial initiative as long as the rules of the game are clear, the authority impartial and all agents know they can rely on the defense of their rights. 
After including variables measuring the possibility of access to financial resources, we have taken into consideration variables detecting personal perceptions. First, we investigate the perception of the risk of failure. Fear of Failure Rate (FRFAIL) is the percentage of the 18-64 population who agree that they see good opportunities but would not start a business for the fear it might fail. Second, we investigate the cognizance of having, or not, an adequate level of knowledge and skills. For this purpose, the GEM detects the SUSKIL indicator which measures the percentage of the 18-64 population who perceive to have the required knowledge and skills to start a business.

In order to detect the "social closeness" of the entrepreneurial initiative, we have also adopted a measure that takes into account the percentage of the 18-64 population who personally knows someone who started a firm in the past two years (KNOENT).

Finally, the institutional variables, such as the annual percentage growth rate of GDP per capita based on constant local currency (GDPCG), or the Corruption Indicator (CORRUP) measuring the perceptions of the extent to which public power is exercised for private gain, including both petty and grand forms of corruption, as well as "capture" of the state by elites and private interests. We also adopt the Global Competitive Index (GCI) rank. This indicator is the results of the ranking of each country based on the GCI. The index measures different aspects of the competitiveness of a country. Competitiveness is defined as "the set of institutions, policies, and factors that determine the level of productivity of a country". The Ease of doing business score (EASEBUS) is the average of the scores for each of the Doing Business topics. This set of variables takes into account a number of steps necessary for entrepreneurship: starting a business, managing building permits, obtaining electricity, registering property, obtaining credit, protecting minority investors, paying taxes, trading across borders, execution of contracts and resolution of insolvencies.

The OECD-INFE has made available the entire framework for the measurement of financial literacy. The framework is based on some simple questions aimed at identifying the knowledge on the different macro-themes of financial knowledge: Time value of money (QK3), Interest paid on loan (QK4), Calculation of interest plus principal (QK5). Indeed, the OECD/INFE survey includes more questions than the ones we use: Compounded capitalization over five years (QK6), Risk and return (QK7a), Inflation (QK7b), Diversification (QK7c). We exclude QK6, QK7a, QK7b, and QK7c from our analysis as they relate to investment and asset allocation themes. These areas of knowledge are relevant for the purposes of financial literacy but, in our opinion, have no direct impact on entrepreneurial intention. The questions are open and multiple-choice and are aimed at measuring the ability to understand and making reasoning in the field of finance. The values assumed by the variables are the ratio between correct answers and total questions.

For our purposes, the ability to answer the first three questions seems to be more relevant. In fact, questions 3,4 and 5 are those directly closest to the hypothetical situation of asking for funding to start a new business.

Table 3 shows the questions of the OECD/INFE survey questionnaire.

To test the theoretical determinants of entrepreneurship we estimated the following model:

$$
\begin{aligned}
& \text { TEA } A_{i}=\alpha+\beta_{1} \times \quad \text { BUSANG }_{i}+\beta_{2} \times \text { GETCRED }_{i}+\beta_{3} \times E \text { NCO }_{i}+\beta_{4} \times \text { FRFAIL }_{i} \\
& +\beta_{5} \times S U S K L_{i}+\beta_{6} \times K_{N O E N T_{i}}+\beta_{7} \times \text { GDPCG }_{i}+\beta_{8} \\
& \times \text { CORRUP }+\beta_{9} \times \text { GCI I }_{i}+\beta_{10} \times \text { FINLIT_INDEX } X_{i}+\varepsilon_{i}
\end{aligned}
$$

where $i$ denote the country of each variable. Following other studies, the GDPCG is lagged one year in order to consider the causality effect. The FINLIT_INDEX variable takes into account one or more combinations of the variables we have adopted in the measurement of financial literacy: QK3, QK4, QK5, FINLIT1, FINLIT2. In addition, some iterations between the variables were tested. Finally, in addition to the main dependent variable TEA, the Nascent Entrepreneurship Rate (SUBOAN) and New Business Ownership Rate (BABYBU) variables were tested in the same model. 
Table 3. Financial knowledge questions.

\section{Text}

Question Code Note that Words or Phrases in $<>$ Can Be Edited to Fit the National Context.

Now imagine that the $<$ brothers $>$ have to wait for one year to get their QK3 share of the $\$ 1000$ and inflation stays at $<X>$ percent. In one year's time will they be able to buy.

QK4 You lend \$25 to a friend one evening and he gives you \$25 back the next day. How much interest has he paid on this loan?

Suppose you put $\$ 100$ into a $<$ no fee, tax free $>$ savings account with a guaranteed interest rate of $2 \%$ per year. You don't make any further payments into this account and you don't withdraw any money. How much would be in the account at the end of the first year, once the
Multiple choice [correct response depends on inflation used]

Open response [correct response 'none' /0]

Open response [correct response \$102] interest payment is made?

\section{Results and Discussion}

\section{Descriptive Statistics and Correlation}

Table 4 shows descriptive statistics of our variables. The mean of the TEA variable is 10.23 , the standard deviation is equal to 4.13 . The minimum and maximum values are, respectively, 4.42 and 6.91. This proves how heterogeneous our sample is in terms of entrepreneurial initiative. The highest values of TEA are observed in Brazil, Thailand, Canada, Estonia, Turkey, Argentina, Latvia, and Indonesia. All of these countries, with the exception of Canada, are characterized by a suboptimal labor market and high unemployment rates. Realistically, in these economies, the entrepreneurial initiative represents a necessity to obtain economic independence.

Table 4. Descriptive Statistics.

\begin{tabular}{ccccccccc}
\hline Variable & $\boldsymbol{n}$ & Mean & S.D. & Min & $\mathbf{0 . 2 5}$ & Mdn & $\mathbf{0 . 7 5}$ & Max \\
\hline TEA & 30 & 10.23 & 4.13 & 4.42 & 6.91 & 9.53 & 14.08 & 19.56 \\
SUBOAN & 30 & 5.30 & 2.36 & 1.96 & 3.86 & 4.66 & 6.05 & 11.65 \\
BABYBU & 30 & 5.13 & 2.98 & 1.67 & 3.04 & 4.45 & 6.10 & 14.04 \\
BUSANG & 30 & 5.01 & 2.73 & 1.29 & 3.15 & 4.30 & 6.46 & 13.67 \\
GETCRED & 30 & 11.90 & 3.58 & 0.00 & 9.00 & 12.00 & 14.00 & 18.00 \\
ENCO & 30 & 24.54 & 11.52 & 12.70 & 16.90 & 22.40 & 27.50 & 70.30 \\
FRFAIL & 30 & 42.09 & 6.96 & 31.11 & 35.62 & 41.24 & 46.09 & 58.41 \\
SUSKIL & 30 & 44.43 & 10.30 & 28.34 & 37.41 & 43.58 & 50.15 & 70.68 \\
KNOENT & 30 & 37.20 & 11.20 & 22.43 & 30.69 & 35.13 & 39.88 & 71.73 \\
GDPCG & 30 & 1.69 & 2.32 & -4.07 & 0.83 & 1.66 & 2.84 & 7.08 \\
CORRUP & 30 & 0.54 & 0.90 & -0.82 & -0.25 & 0.25 & 1.40 & 2.24 \\
GCI & 30 & 4.71 & 0.50 & 3.79 & 4.31 & 4.52 & 5.13 & 5.53 \\
EASEBUS & 30 & 72.19 & 8.98 & 54.52 & 66.24 & 74.81 & 79.13 & 84.32 \\
QK3 & 30 & 59.20 & 17.51 & 14.00 & 52.00 & 63.00 & 71.00 & 83.00 \\
QK4 & 30 & 82.47 & 10.87 & 54.00 & 76.00 & 85.00 & 92.00 & 98.00 \\
QK5 & 30 & 56.17 & 16.46 & 12.00 & 47.00 & 57.00 & 68.00 & 79.00 \\
FINLIT1 & 30 & 141.67 & 25.41 & 90.00 & 124.00 & 149.00 & 157.00 & 181.00 \\
FINLIT2 & 30 & 197.83 & 33.93 & 137.00 & 178.00 & 201.50 & 218.00 & 260.00 \\
\hline
\end{tabular}


Table 5 shows the Pearson correlation coefficients between the different variables measured in the sample. The level of significance and the representation with stars of the minimum significance leads to a better reading of the results. The correlations between the variables do not show high values that could affect the results of the regressions. Measures of financial literacy are positively correlated; this is as expected. To avoid multicollinearity problems and to investigate the research hypotheses separately, we estimated the base model by adding the literacy variables individually. The univariate analysis shows the positive and significant correlation between SUSKIL and three variables that estimate entrepreneurship: TEA, SUBOAN and BABYBU. This is expected evidence and in line with previous research findings. The perception of sufficient knowledge is essential in choosing to become an entrepreneur. Similarly, KNOENT shows a significant and positive relationship with BABYBU and BUSANG. The presence of a network of entrepreneurs who share experiences allows entrepreneurship and the ease of financing with private capital to increase. The significant and positive relationship between EASEBUS and GETCRED is expected and logically explainable: the ability to access sources of funding makes it easier to start up entrepreneurial activities. Instead, the significant and negative relationship between EASEBUS and BABYBU is unexpected and counterintuitive. However, it is the only relationship of EASEBUS and significant entrepreneurship variables, as we have no significant results in the other cases. Regarding the financial literacy variables, we have positive and significant correlations between QK4 and SUBOAN, FINLIT1 and SUBOAN. Finally, the results show positive and significant correlations between all financial literacy variables and EASEBUS. This confirms our expectations regarding the centrality of knowledge in financial matters. The univariate analysis shows encouraging results that can be explored in the subsequent multivariate analysis.

Table 6 reports the results of our analyzes. We estimated the model with an OLS procedure. The variables concerning financial literacy were investigated individually in order to accurately analyze the influence of the financial argument measured on the level of entrepreneurship. The quality of the model increases as the number of variables increases. More precisely, the adjusted R-squared index increases with the addition of the variables concerning financial literacy. Depending on the financial literacy variable adopted, our model shows R-sq adjusted with values ranging from 0.224 to 0.471 . The maximum value is reached in the model that adopts FINLIT2. This last is the variable that summarizes all the three questions we considered, and therefore that presents a greater informative content. This supports the relevance of the covariate that measures financial literacy on our target variable. In view of the relatively small number of observations, this result is appreciable.

First, it is necessary to detect the level of significance for all the estimates of the SUSKIL variable. The adults' perception of their adequate knowledge and skills is a characteristic element of those who venture into starting a new business. Since it is a personal perception, institutional policies are complex. However, it is possible to identify actions and policy suitable to increase self-confidence and one's abilities. We particularly refer to the educational system. An efficient education system allows citizens to be more prepared for life's challenges. The field of entrepreneurship falls within the objectives of a healthy social system. Therefore, it seems reasonable to include financial and entrepreneurship topics in the individual's training process.

Our first hypothesis concerns the relationship between financial literacy and entrepreneurship. All financial literacy variables are significant except QK3. The QK3 question is likely far too basic to measure financial knowledge. Questions QK4 and QK5 both have positive and significant coefficients. A higher degree of competence also corresponds to greater entrepreneurship. These results confirm our first hypothesis. 
Table 5. Correlation Matrix.

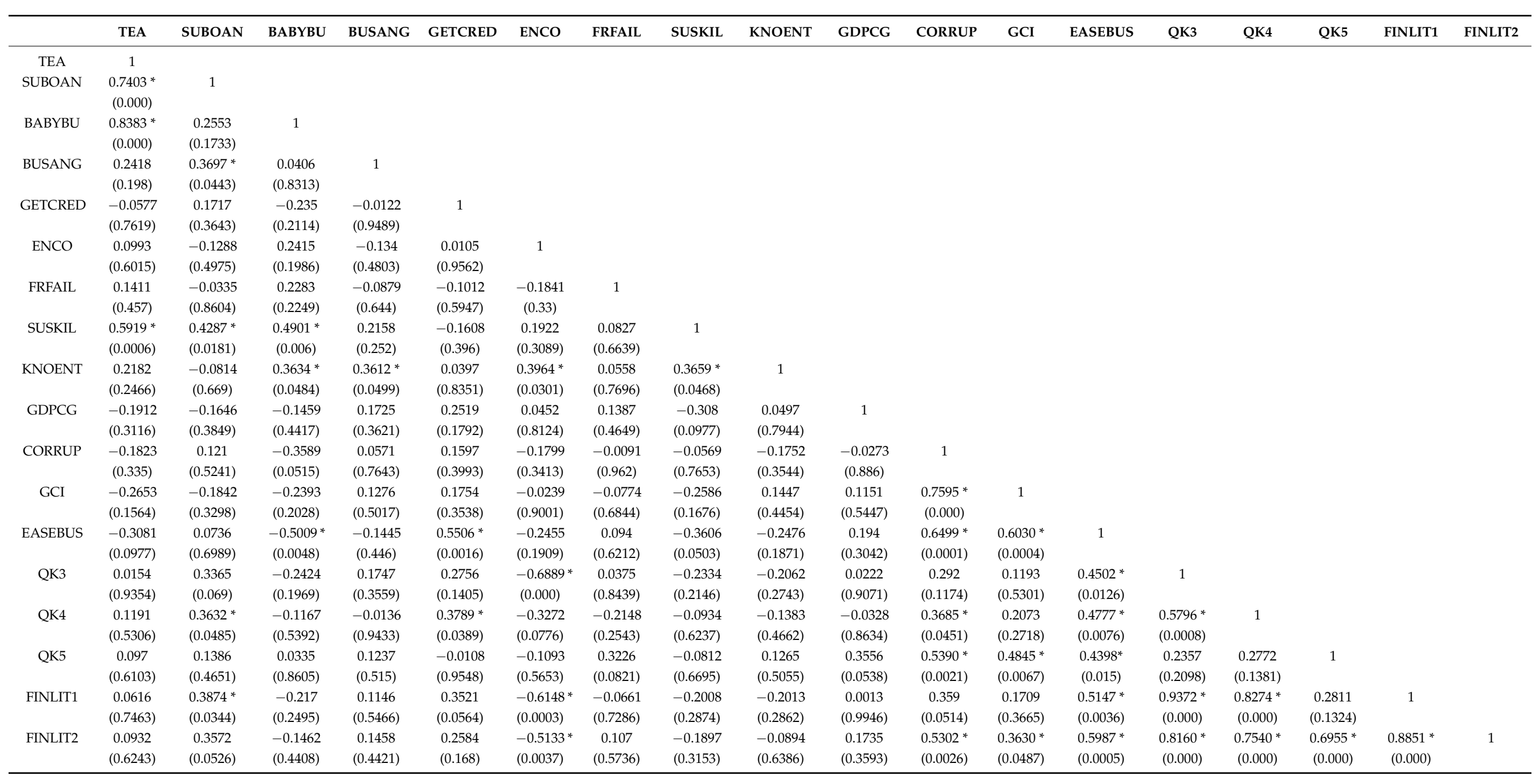

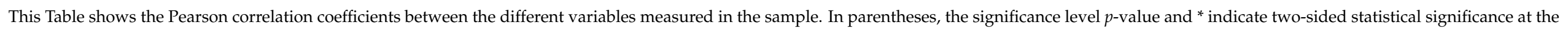
$5 \%\left({ }^{*} p<0.05\right)$. 
Regarding our second research hypothesis, models 5 and 6 estimate the equation by adopting FINLIT 1 and FINLIT2, respectively. The regression shows the best performance, in terms of adjusted R-squared, in model 6. FINLIT2 takes into account all three questions for the survey of financial literacy that we considered closest to the needs of a business owner. The coefficient is positive and statistically significant at $0.001 \%$. Therefore, it is reasonable to state the positive relationship between financial education and entrepreneurship.

In the last estimated model, it is also possible to identify other significant relationships. In particular, the variables ENCO, KNOENT and CORRUP. The resulting coefficients are positive for ENCO and negative for ENCO and CORRUP, respectively. The signs of the coefficients are in line with the expectations and with the results already obtained in previous research that can be found in the literature.

The ENCO and CORRUP variables both measure two aspects related to institutions. The ENCO variable measures the costs related to the defense of rights. The CORRUP variable is an estimate of the phenomenon of corruption within the country. The reduction in costs related to the defense of one's rights and the resolution of disputes allows greater effectiveness of entrepreneurial action throughout the life of the company. In the initial phase, the perception of an inefficient administration of justice holds back both the initiative of new businesses and the attraction of capital to finance entrepreneurship. The result is a vicious circle that reduces the economic thrust. The CORRUP variable evaluates the level of corruption in the country. Unfortunately, corruption is a serious disease for every social system. The presence of corruption phenomena is not limited to the decrease in the efficiency of economic activity. When corruption becomes apparent it constitutes a barrier to entry for any business idea.

Lastly, the KNOENT variable is a measure of the network in which the entrepreneurial initiative takes place. The survey is based on a simple question aimed at verifying the knowledge of an entrepreneur in the social sphere of the interviewee. This result is not in line with our expectations. The expected coefficient should be positive: the knowledge of an entrepreneur should increase the propensity to start new businesses. In addition, where the entrepreneurial activity is greater, it is more likely to know another entrepreneur. The analysis of the univariate relationship between the two variables highlights a positive relationship. In our model, the coefficient is likely affected by a relationship that the linear formulation is not able to perceive.

The other variables have no statistically significant estimates. However, they deserve an interpretation of the evidence. The BUSANG and GETCREDIT variables both have a positive coefficient. The first measures the tendency of citizens to finance new businesses, the second measures the ease of access to finance from the banking system. The coefficient is in line with expectations and with the results of previous studies. The empirical evidence demonstrates how important the ability to access sources of finance is in starting a new business. The FRFAIL variable has a positive coefficient. This result is not expected and contrary to the evidence of previous empirical studies: the presence of fears of failure are a brake on entrepreneurship. Indeed, this counterintuitive and unexpected relationship is devoid of statistical significance in the univariate analysis and also in the six different estimates of the multivariate analysis. The variable GCPCG assumes a negative value and in this case, does not appear significant. Indeed, given that the countries in our sample are characterized by very heterogeneous levels of development, the result may be affected by this diversity. While it is likely to expect a level of entrepreneurship in growing economies, on the other hand, the descriptive statistics show a high level of entrepreneurship in less efficient economies where entrepreneurial activity is a necessity for personal and family subsistence, Germany's low level of TEA is proof of this. The GCI index is positive and not significant. This confirms the relevance of competitiveness in entrepreneurship. Finally, the EASEBUS index has a negative coefficient and is not statistically significant. 
Table 6. Results of the estimates of the coefficients of the model. TEA dependent variable.

\begin{tabular}{|c|c|c|c|c|c|c|}
\hline TEA & (1) & (2) & (3) & (4) & (5) & (6) \\
\hline \multirow[t]{2}{*}{ BUSANG } & 0.332 & 0.230 & 0.405 & 0.345 & 0.284 & 0.297 \\
\hline & (1.00) & $(0.72)$ & (1.33) & (1.19) & $(0.97)$ & (1.14) \\
\hline \multirow[t]{2}{*}{ GETCRED } & 0.200 & 0.171 & 0.138 & 0.472 & 0.136 & 0.312 \\
\hline & $(0.71)$ & $(0.64)$ & $(0.53)$ & $(1.77)$ & $(0.55)$ & (1.41) \\
\hline \multirow[t]{2}{*}{ ENCO } & 0.0245 & 0.141 & 0.0862 & 0.0343 & 0.167 & $0.162 *$ \\
\hline & $(0.31)$ & (1.44) & (1.13) & $(0.50)$ & (1.90) & $(2.26)$ \\
\hline \multirow[t]{2}{*}{ FRFAIL } & 0.114 & 0.154 & 0.217 & 0.0514 & 0.213 & 0.165 \\
\hline & $(0.96)$ & (1.35) & (1.85) & $(0.48)$ & (1.92) & (1.76) \\
\hline \multirow[t]{2}{*}{ SUSKIL } & 0.220 * & 0.270 * & 0.220 * & 0.239 * & $0.266^{* *}$ & $0.274^{* *}$ \\
\hline & $(2.21)$ & $(2.75)$ & $(2.43)$ & (2.73) & $(2.98)$ & (3.46) \\
\hline \multirow[t]{2}{*}{ KNOENT } & -0.0698 & -0.135 & -0.122 & -0.163 & -0.160 & $-0.211^{*}$ \\
\hline & $(-0.68)$ & $(-1.30)$ & $(-1.26)$ & $(-1.68)$ & $(-1.65)$ & $(-2.36)$ \\
\hline \multirow[t]{2}{*}{ GDPCG } & -0.213 & -0.156 & -0.199 & -0.627 & -0.153 & -0.418 \\
\hline & $(-0.58)$ & $(-0.45)$ & $(-0.60)$ & $(-1.76)$ & $(-0.48)$ & $(-1.44)$ \\
\hline \multirow[t]{2}{*}{ CORRUP } & -1.028 & -1.898 & -1.874 & -2.836 & -2.327 & -3.358 * \\
\hline & $(-0.61)$ & $(-1.14)$ & $(-1.19)$ & $(-1.75)$ & $(-1.49)$ & $(-2.30)$ \\
\hline \multirow[t]{2}{*}{ GCI } & 1.010 & 3.391 & 2.698 & 2.266 & 4.183 & 4.717 \\
\hline & $(0.32)$ & (1.04) & $(0.91)$ & $(0.81)$ & (1.38) & (1.77) \\
\hline \multirow[t]{2}{*}{ EASEBUS } & -0.0586 & -0.156 & -0.153 & -0.165 & -0.204 & -0.259 \\
\hline & $(-0.36)$ & $(-0.95)$ & $(-0.99)$ & $(-1.11)$ & $(-1.32)$ & $(-1.86)$ \\
\hline \multirow[t]{2}{*}{ QK3 } & & 0.122 & & & & \\
\hline & & $(1.81)$ & & & & \\
\hline \multirow[t]{2}{*}{ QK4 } & & & 0.182 * & & & \\
\hline & & & $(2.24)$ & & & \\
\hline \multirow[t]{2}{*}{ QK5 } & & & & 0.161 * & & \\
\hline & & & & $(2.63)$ & & \\
\hline \multirow[t]{2}{*}{ FINLIT1 } & & & & & 0.110 * & \\
\hline & & & & & $(2.59)$ & \\
\hline \multirow[t]{2}{*}{ FINLIT2 } & & & & & & $0.101^{* *}$ \\
\hline & & & & & & (3.64) \\
\hline \multirow[t]{2}{*}{ _cons } & -6.009 & -20.59 & -25.23 & -9.907 & -30.82 & -31.28 \\
\hline & $(-0.36)$ & $(-1.15)$ & $(-1.43)$ & $(-0.67)$ & $(-1.75)$ & $(-2.10)$ \\
\hline $\mathrm{N}$ & 30 & 30 & 30 & 30 & 30 & 30 \\
\hline adj. R-sq & 0.131 & 0.224 & 0.283 & 0.338 & 0.331 & 0.471 \\
\hline
\end{tabular}

Note: This table shows the regression coefficients, $t$-values and significance level of each variable adopted to estimate our model. Dependent variable TEA. Each column (1 to 6) shows the results of the model estimates with a different financial literacy variable. In parentheses, the $t$ statistics; ${ }^{* *}$, and * indicate two-sided statistical significance at the $1 \%, 5 \%$, and $10 \%$ levels, respectively $\left({ }^{*} p<0.05 ;{ }^{* *} p<0.01\right)$.

\section{Robustness and Study Limitations}

In order to validate our results and analyze relationships in specific situations, we estimated the model by adopting the two sub-variables of the TEA index which specifically measure nascent entrepreneurs (SUBOAN) and entrepreneurs who are currently owner/managers of young companies (started no more than 3.5 years ago). Tables 7 and 8 show the results of the coefficient estimates for the dependent variable SUBOAN and BUSANG, respectively. 
In both comparison models, the financial literacy measurement variables maintain the sign of the estimated coefficient and statistical significance. This empirical evidence confirms a valid relationship with a very heterogeneous sample of countries. The relationship remains such while changing the way entrepreneurship is measured and therefore its definition.

Table 7. Results of the estimates of the coefficients of the model. SUBOAN dependent variable.

\begin{tabular}{|c|c|c|c|c|c|c|}
\hline SUBOAN & (1) & (2) & (3) & (4) & (5) & (6) \\
\hline BUSANG & $\begin{array}{l}0.452 * \\
(2.69)\end{array}$ & $\begin{array}{l}0.404 * \\
(2.48)\end{array}$ & $\begin{array}{c}0.482^{* *} \\
(3.01)\end{array}$ & $\begin{array}{l}0.458^{* *} \\
(2.97)\end{array}$ & $\begin{array}{l}0.431 * \\
(2.80)\end{array}$ & $\begin{array}{c}0.437^{* *} \\
(3.06)\end{array}$ \\
\hline GETCRED & $\begin{array}{c}0.0850 \\
(0.60)\end{array}$ & $\begin{array}{c}0.0714 \\
(0.53)\end{array}$ & $\begin{array}{c}0.0592 \\
(0.44)\end{array}$ & $\begin{array}{l}0.202 \\
(1.43)\end{array}$ & $\begin{array}{c}0.0567 \\
(0.43)\end{array}$ & $\begin{array}{l}0.134 \\
(1.10)\end{array}$ \\
\hline ENCO & $\begin{array}{c}0.0164 \\
(0.42)\end{array}$ & $\begin{array}{l}0.0710 \\
(1.42)\end{array}$ & $\begin{array}{l}0.0417 \\
(1.04)\end{array}$ & $\begin{array}{l}0.0206 \\
(0.57)\end{array}$ & $\begin{array}{l}0.0792 \\
(1.72)\end{array}$ & $\begin{array}{l}0.0762 \\
(1.94)\end{array}$ \\
\hline FRFAIL & $\begin{array}{c}-0.00967 \\
(-0.16)\end{array}$ & $\begin{array}{c}0.00915 \\
(0.16)\end{array}$ & $\begin{array}{l}0.0327 \\
(0.53)\end{array}$ & $\begin{array}{l}-0.0364 \\
(-0.65)\end{array}$ & $\begin{array}{c}0.0338 \\
(0.58)\end{array}$ & $\begin{array}{c}0.0128 \\
(0.25)\end{array}$ \\
\hline SUSKIL & $\begin{array}{c}0.0871 \\
(1.74)\end{array}$ & $\begin{array}{l}0.111 * \\
(2.21)\end{array}$ & $\begin{array}{l}0.0872 \\
(1.83)\end{array}$ & $\begin{array}{c}0.0950 \\
(2.06)\end{array}$ & $\begin{array}{l}0.107^{*} \\
(2.29)\end{array}$ & $\begin{array}{c}0.110^{*} \\
(2.55)\end{array}$ \\
\hline KNOENT & $\begin{array}{l}-0.0492 \\
(-0.95)\end{array}$ & $\begin{array}{l}-0.0796 \\
(-1.50)\end{array}$ & $\begin{array}{l}-0.0705 \\
(-1.39)\end{array}$ & $\begin{array}{l}-0.0892 \\
(-1.74)\end{array}$ & $\begin{array}{l}-0.0889 \\
(-1.75)\end{array}$ & $\begin{array}{l}-0.111 \text { * } \\
(-2.26)\end{array}$ \\
\hline GDPCG & $\begin{array}{l}-0.175 \\
(-0.95)\end{array}$ & $\begin{array}{l}-0.149 \\
(-0.84)\end{array}$ & $\begin{array}{l}-0.170 \\
(-0.97)\end{array}$ & $\begin{array}{l}-0.353 \\
(-1.88)\end{array}$ & $\begin{array}{l}-0.149 \\
(-0.88)\end{array}$ & $\begin{array}{l}-0.265 \\
(-1.67)\end{array}$ \\
\hline CORRUP & $\begin{array}{l}0.479 \\
(0.56)\end{array}$ & $\begin{array}{c}0.0720 \\
(0.08)\end{array}$ & $\begin{array}{l}0.132 \\
(0.16)\end{array}$ & $\begin{array}{l}-0.296 \\
(-0.34)\end{array}$ & $\begin{array}{l}-0.0925 \\
(-0.11)\end{array}$ & $\begin{array}{l}-0.536 \\
(-0.67)\end{array}$ \\
\hline GCI & $\begin{array}{l}-2.340 \\
(-1.47)\end{array}$ & $\begin{array}{l}-1.225 \\
(-0.74)\end{array}$ & $\begin{array}{l}-1.646 \\
(-1.05)\end{array}$ & $\begin{array}{l}-1.801 \\
(-1.22)\end{array}$ & $\begin{array}{l}-0.943 \\
(-0.59)\end{array}$ & $\begin{array}{l}-0.725 \\
(-0.50)\end{array}$ \\
\hline EASEBUS & $\begin{array}{l}0.104 \\
(1.26)\end{array}$ & $\begin{array}{l}0.0583 \\
(0.70)\end{array}$ & $\begin{array}{l}0.0649 \\
(0.80)\end{array}$ & $\begin{array}{c}0.0582 \\
(0.74)\end{array}$ & $\begin{array}{c}0.0399 \\
(0.49)\end{array}$ & $\begin{array}{c}0.0166 \\
(0.22)\end{array}$ \\
\hline QK3 & & $\begin{array}{c}0.0572 \\
(1.66)\end{array}$ & & & & \\
\hline QK4 & & & $\begin{array}{l}0.0747 \\
(1.75)\end{array}$ & & & \\
\hline QK5 & & & & $\begin{array}{c}0.0692 * \\
(2.13)\end{array}$ & & \\
\hline FINLIT1 & & & & & $\begin{array}{c}0.0486 \text { * } \\
(2.17)\end{array}$ & \\
\hline FINLIT2 & & & & & & $\begin{array}{c}0.0442 \text { ** } \\
(2.89)\end{array}$ \\
\hline _cons & $\begin{array}{l}3.552 \\
(0.42)\end{array}$ & $\begin{array}{l}-3.272 \\
(-0.36)\end{array}$ & $\begin{array}{l}-4.348 \\
(-0.47)\end{array}$ & $\begin{array}{l}1.880 \\
(0.24)\end{array}$ & $\begin{array}{l}-7.375 \\
(-0.80)\end{array}$ & $\begin{array}{l}-7.456 \\
(-0.91)\end{array}$ \\
\hline $\begin{array}{c}\mathrm{N} \\
\text { adj. R-sq }\end{array}$ & $\begin{array}{c}30 \\
0.327\end{array}$ & $\begin{array}{c}30 \\
0.384\end{array}$ & $\begin{array}{c}30 \\
0.393\end{array}$ & $\begin{array}{c}30 \\
0.433\end{array}$ & $\begin{array}{c}30 \\
0.437\end{array}$ & $\begin{array}{c}30 \\
0.515\end{array}$ \\
\hline
\end{tabular}

Note: This table shows the regression coefficients, $t$-values and significance level of each variable adopted to estimate our model. Dependent variable SUBOAN. Each column (1 to 6) shows the results of the model estimates with a different financial literacy variable. In parentheses, the $t$ statistics; ${ }^{* *}$, and ${ }^{*}$ indicate two-sided statistical significance at the $1 \%, 5 \%$, and $10 \%$ levels, respectively $\left({ }^{*} p<0.05 ;{ }^{* *} p<0.01\right)$. 
Table 8. Results of the estimates of the coefficients of the model. BABYBU dependent variable. In parentheses, the t statistics $\left({ }^{*} p<0.05 ;{ }^{* *} p<0.01\right)$.

\begin{tabular}{|c|c|c|c|c|c|c|}
\hline BABYBU & (1) & (2) & (3) & (4) & (5) & (6) \\
\hline BUSANG & $\begin{array}{l}-0.115 \\
(-0.52)\end{array}$ & $\begin{array}{l}-0.172 \\
(-0.79)\end{array}$ & $\begin{array}{c}-0.0688 \\
(-0.34)\end{array}$ & $\begin{array}{l}-0.106 \\
(-0.54)\end{array}$ & $\begin{array}{l}-0.143 \\
(-0.71)\end{array}$ & $\begin{array}{l}-0.136 \\
(-0.74)\end{array}$ \\
\hline GETCRED & $\begin{array}{l}0.101 \\
(0.54)\end{array}$ & $\begin{array}{c}0.0849 \\
(0.47)\end{array}$ & $\begin{array}{c}0.0619 \\
(0.36)\end{array}$ & $\begin{array}{l}0.268 \\
(1.48)\end{array}$ & $\begin{array}{c}0.0630 \\
(0.37)\end{array}$ & $\begin{array}{l}0.169 \\
(1.08)\end{array}$ \\
\hline ENCO & $\begin{array}{c}0.00977 \\
(0.19)\end{array}$ & $\begin{array}{c}0.0762 \\
(1.15)\end{array}$ & $\begin{array}{c}0.0486 \\
(0.95)\end{array}$ & $\begin{array}{c}0.0158 \\
(0.34)\end{array}$ & $\begin{array}{c}0.0952 \\
(1.58)\end{array}$ & $\begin{array}{c}0.0929 \\
(1.85)\end{array}$ \\
\hline FRFAIL & $\begin{array}{l}0.125 \\
(1.60)\end{array}$ & $\begin{array}{l}0.148 \\
(1.91)\end{array}$ & $\begin{array}{c}0.190 * \\
(2.42)\end{array}$ & $\begin{array}{c}0.0871 \\
(1.20)\end{array}$ & $\begin{array}{l}0.185 \text { * } \\
(2.43)\end{array}$ & $\begin{array}{c}0.157 \text { * } \\
(2.38)\end{array}$ \\
\hline SUSKIL & $\begin{array}{l}0.133 \\
(2.01)\end{array}$ & $\begin{array}{l}0.161 \text { * } \\
(2.42)\end{array}$ & $\begin{array}{c}0.133 * \\
(2.18)\end{array}$ & $\begin{array}{l}0.144 \text { * } \\
(2.42)\end{array}$ & $\begin{array}{l}0.160 * \\
(2.62)\end{array}$ & $\begin{array}{c}0.165^{* *} \\
(2.97)\end{array}$ \\
\hline KNOENT & $\begin{array}{c}-0.0209 \\
(-0.31)\end{array}$ & $\begin{array}{l}-0.0579 \\
(-0.82)\end{array}$ & $\begin{array}{c}-0.0535 \\
(-0.83)\end{array}$ & $\begin{array}{c}-0.0782 \\
(-1.19)\end{array}$ & $\begin{array}{c}-0.0748 \\
(-1.13)\end{array}$ & $\begin{array}{l}-0.106 \\
(-1.70)\end{array}$ \\
\hline GDPCG & $\begin{array}{c}-0.0471 \\
(-0.19)\end{array}$ & $\begin{array}{c}-0.0147 \\
(-0.06)\end{array}$ & $\begin{array}{c}-0.0386 \\
(-0.17)\end{array}$ & $\begin{array}{l}-0.302 \\
(-1.25)\end{array}$ & $\begin{array}{l}-0.0114 \\
(-0.05)\end{array}$ & $\begin{array}{l}-0.172 \\
(-0.84)\end{array}$ \\
\hline CORRUP & $\begin{array}{c}-1.487 \\
(-1.33)\end{array}$ & $\begin{array}{l}-1.983 \\
(-1.76)\end{array}$ & $\begin{array}{l}-2.020 \\
(-1.91)\end{array}$ & $\begin{array}{l}-2.597 * \\
(-2.35)\end{array}$ & $\begin{array}{l}-2.265 * \\
(-2.12)\end{array}$ & $\begin{array}{l}-2.897 * \\
(-2.82)\end{array}$ \\
\hline GCI & $\begin{array}{l}3.220 \\
(1.54)\end{array}$ & $\begin{array}{l}4.576 \\
(2.07)\end{array}$ & $\begin{array}{l}4.282 * \\
(2.15)\end{array}$ & $\begin{array}{l}3.991 \\
(2.10)\end{array}$ & $\begin{array}{l}5.119 * \\
(2.47)\end{array}$ & $\begin{array}{c}5.462^{* *} \\
(2.92)\end{array}$ \\
\hline EASEBUS & $\begin{array}{l}-0.160 \\
(-1.48)\end{array}$ & $\begin{array}{l}-0.216 \\
(-1.94)\end{array}$ & $\begin{array}{l}-0.220^{*} \\
(-2.12)\end{array}$ & $\begin{array}{l}-0.226 \text { * } \\
(-2.23)\end{array}$ & $\begin{array}{l}-0.247 * \\
(-2.34)\end{array}$ & $\begin{array}{c}-0.282^{* *} \\
(-2.88)\end{array}$ \\
\hline QK3 & & $\begin{array}{c}0.0696 \\
(1.52)\end{array}$ & & & & \\
\hline QK4 & & & $\begin{array}{l}0.114 \\
(2.10)\end{array}$ & & & \\
\hline QK5 & & & & $\begin{array}{c}0.0991 \text { * } \\
(2.38)\end{array}$ & & \\
\hline FINLIT1 & & & & & $\begin{array}{c}0.0660 * \\
(2.26)\end{array}$ & \\
\hline FINLIT2 & & & & & & $\begin{array}{c}0.0613^{* *} \\
(3.14)\end{array}$ \\
\hline _cons & $\begin{array}{l}-8.846 \\
(-0.79)\end{array}$ & $\begin{array}{l}-17.15 \\
(-1.41)\end{array}$ & $\begin{array}{l}-20.93 \\
(-1.77)\end{array}$ & $\begin{array}{l}-11.24 \\
(-1.11)\end{array}$ & $\begin{array}{l}-23.70 \\
(-1.96)\end{array}$ & $\begin{array}{l}-24.13 \text { * } \\
(-2.31)\end{array}$ \\
\hline $\begin{array}{c}\mathrm{N} \\
\text { adj. R-sq }\end{array}$ & $\begin{array}{c}30 \\
0.266\end{array}$ & $\begin{array}{c}30 \\
0.313\end{array}$ & $\begin{array}{c}30 \\
0.377\end{array}$ & $\begin{array}{c}30 \\
0.410\end{array}$ & $\begin{array}{c}30 \\
0.396\end{array}$ & $\begin{array}{c}30 \\
0.499\end{array}$ \\
\hline
\end{tabular}

Note: This table shows the regression coefficients, $t$-values and significance level of each variable adopted to estimate our model. Dependent variable BABYBU. Each column (1 to 6) shows the results of the model estimates with a different financial literacy variable. In parentheses, the $t$ statistics; ${ }^{* *}$, and * indicate two-sided statistical significance at the $1 \%, 5 \%$, and $10 \%$ levels, respectively $\left({ }^{*} p<0.05 ;{ }^{* *} p<0.01\right)$.

In the model relating to the SUBOAN variable, where the concept of entrepreneurship refers only to companies in the initial, almost early-stage life cycle, in addition to the financial literacy variables, the BUSANG variable assumes great importance. This measured the propensity of the survey sample to provide financing to new businesses that are not executed through investments in stocks or funds. The propensity of a company to entrepreneurship is measured not only through the propensity to start a new business but also through the propensity to finance new business ventures with risk capital. The 
positivity of the SUSKIL variable relating to the knowledge and skills deemed necessary remains confirmed. Nevertheless, interpreting the relation regarding KNOENT remains difficult. Some relationships between variables that appeared statistically significant in the initial model are lost: ENCO and CORRUP (Table 7).

In the model where the dependent variable is BABYBU, they are defined as new entrepreneurs or owners/managers of businesses started less than 3.5 years ago. In this case, the results are similar to the initial model except for the loss of statistical significance for the ENCO variable, and evidence of a significant relationship for FRFAIL but with an inverse sign compared to expectations.

In the model where the dependent variable is BABYBU, they are defined as new entrepreneurs or owners/managers of businesses started less than 3.5 years ago. Additionally, in this case, the relationships regarding the variables of financial literacy remain constant and statistically significant. With regard to the other variables, it is necessary to note the loss of statistical significance for ENCO and KNOENT. Instead, two statistically significant relationships are highlighted, but with the opposite sign compared to expectations: FRFAIL and EASEBUS. Lastly, the positive relationship with GCI acquires statistical significance and is in line with expectations (Table 8).

\section{Conclusions}

Entrepreneurship implies economic growth and social well-being. Our research based on GEM and OECD data confirms the positive and statistically significant relationship between financial literacy and entrepreneurship, no matter the countries investigated.

Previous studies find a positive relationship between entrepreneurship and economic education in school systems. In this paper, we shed new light on the effects of financial literacy on entrepreneurship. Our results confirm the positive and significant relationship between financial literacy and entrepreneurship.

However, our analysis suffers from some limitations. The instability of some of the results and the difficulty in interpreting some relationships is mainly due to the survey sample. Initially, the sample includes the countries participating in the two OECD surveys on financial literacy. This sample appears to be very heterogeneous and limited in number. Despite the combination of two separate surveys, the sample counts 30 countries. If compared with a large number of respondents of the GEM survey on entrepreneurship, it is clear how much an investigation effort is still necessary for the field of financial literacy. The survey approach was based on OLS estimates. A more complex methodology is currently not adoptable, given the absence of empirical data. Precisely, similar to studies on entrepreneurship, the approach based on panel data appears to be more rewarding. However, the irregular timing of financial literacy studies, the limits of the samples in terms of countries and the variability of the samples from one survey to another, make this alternative impossible now.

Future research developments should benefit from the experience of the GEM. The effort made by GEM is an example of the importance of having stable frameworks shared by researchers. This allows surveys and research to be carried out constantly over time. The research results immediately undergo a qualitative increase. The same should be performed in the field of financial literacy.

Given the relationship identified in this paper, we suggest that policymakers increase investments in economic and entrepreneurial training within their national education systems. Financial literacy highlights a strong relationship with entrepreneurship. The benefits of financial literacy extend far beyond the strictly economic phenomenon given the implications of financial knowledge in the lives of the citizens. Two central consequences emerge from the study. First, the need to set up a shared and stable survey framework. Consistent methods and reliable data are the basis for the development of interesting lines of research. Second, it is advisable to increase the weight of financial literacy topics in economic disciplines within the educational systems worldwide. 
Author Contributions: All authors contributed equally to all aspects of the study reported in this paper. All authors have read and agreed to the published version of the manuscript.

Funding: This study received no external funding.

Institutional Review Board Statement: Not applicable.

Informed Consent Statement: Not applicable.

Data Availability Statement: Not applicable.

Acknowledgments: Authors would like to acknowledge the support and advice provided by the Special Issue editor, as well as the anonymous reviewers, which greatly improved the quality of the paper with their comments.

Conflicts of Interest: The authors declare no conflict of interest.

\section{References}

1. Schumpeter, J.; Backhaus, U. The theory of economic development. In Joseph Alois Schumpeter; Springer: Berlin/Heidelberg, Germany, 2003; pp. 61-116.

2. Shane, S.; Venkataraman, S. The promise of entrepreneurship as a field of research. Acad. Manag. Rev. 2000, 25, 217-226. [CrossRef]

3. Acs, Z.J.; Desai, S.; Hessels, J. Entrepreneurship, economic development and institutions. Small Bus. Econ. 2008, 31, $219-234$. [CrossRef]

4. Naudé, W. Entrepreneurship in Economic Development; WIDER Research Paper; WIDER: Helskinski, Finland, 2008.

5. Wiklund, J.; Nikolaev, B.; Shir, N.; Foo, M.-D.; Bradley, S. Entrepreneurship and well-being: Past, present, and future. J. Bus. Ventur. 2019, 34, 579-588. [CrossRef]

6. Shir, N.; Nikolaev, B.N.; Wincent, J. Entrepreneurship and well-being: The role of psychological autonomy, competence, and relatedness. J. Bus. Ventur. 2019, 34, 105875. [CrossRef]

7. Schlaegel, C.; Koenig, M. Determinants of entrepreneurial intent: A meta-analytic test and integration of competing models. Entrep. Theory Pract. 2014, 38, 291-332. [CrossRef]

8. Castaño, M.S.; Méndez, M.T.; Galindo, M.Á. The effect of social, cultural, and economic factors on entrepreneurship. J. Bus. Res. 2015, 68, 1496-1500. [CrossRef]

9. Galindo, M.-Á.; Méndez, M.T. Entrepreneurship, economic growth, and innovation: Are feedback effects at work? J. Bus. Res. 2014, 67, 825-829. [CrossRef]

10. Voda, A.I.; Butnaru, G.I.; Butnaru, R.C. Enablers of entrepreneurial activity across the european union-an analysis using GEM individual data. Sustainability 2020, 12, 1022. [CrossRef]

11. Sadiq Kasum, A.; Gunu, U. Entrepreneurship in Underdeveloped Economies: A Study of Nigeria. Stud. Mater. 2017, 48-61.

12. Piasecki, B.; Rogut, A. The EU's internal market and prospects of Polish SMEs. Acta Univ. Lodz. Folia Oecon. 2004, 178, 53-74.

13. Sternberg, R.; Wennekers, S. Determinants and effects of new business creation using global entrepreneurship monitor data. Small Bus. Econ. 2005, 24, 193-203. [CrossRef]

14. Zajkowski, R.; Domańska, A. Differences in perception of regional pro-entrepreneurial policy: Does obtaining support change a prospect? Oecon. Copernic. 2019, 10, 359-384. [CrossRef]

15. Eisenmann, T.R. Entrepreneurship: A Working Definition. Harv. Bus. Rev. 2013, 10, 1-3.

16. Porter, M.E. The competitive advantage of nations. Harv. Bus. Rev. 1990, 68, 73-93.

17. Baumol, W.J. Formal entrepreneurship theory in economics: Existence and bounds. J. Bus. Ventur. 1993, 8, 197-210. [CrossRef]

18. Thomson Reuters Thomson Reuters ESG Scores. 2017, 12. Available online: https://www.refinitiv.com/en/sustainable-finance / esg-scores (accessed on 21 April 2021).

19. Miłek, D. Spatial differentiation in the social and economic development level in Poland. Equilib. Q. J. Econ. Econ. Policy 2018, 13, 487-507. [CrossRef]

20. Wong, P.K.; Ho, Y.P.; Autio, E. Entrepreneurship, innovation and economic growth: Evidence from GEM data. Small Bus. Econ. 2005, 24, 335-350. [CrossRef]

21. Chen, Y.; Gong, X.; Chu, C.C.; Cao, Y. Access to the internet and access to finance: Theory and evidence. Sustainability 2018, 10, 2534. [CrossRef]

22. Zygmunt, J. The effect of changes in the economic structure on entrepreneurial activity in a transition economy: The case of Poland. Equilib. Q. J. Econ. Econ. Policy 2020, 15, 49-62. [CrossRef]

23. Kobylińska, U.; Lavios, J.J. Development of research on the university entrepreneurship ecosystem: Trends and areas of interest of researchers based on a systematic review of literature. Oecon. Copernic. 2020, 11, 117-133. [CrossRef]

24. Aparicio, S.; Turro, A.; Noguera, M. Entrepreneurship and Intrapreneurship in Social, Sustainable, and Economic Development: Opportunities and Challenges for Future Research. Sustainability 2020, 12, 8958. [CrossRef]

25. Gast, J.; Gundolf, K.; Cesinger, B. Doing business in a green way: A systematic review of the ecological sustainability entrepreneurship literature and future research directions. J. Clean. Prod. 2017, 147, 44-56. [CrossRef] 
26. Fernandes, C.I.; Veiga, P.M.; Ferreira, J.J.M.; Hughes, M. Green growth versus economic growth: Do sustainable technology transfer and innovations lead to an imperfect choice? Bus. Strateg. Environ. 2021. [CrossRef]

27. Anton, S.G.; Bostan, I. The role of access to finance in explaining cross-national variation in entrepreneurial activity: A panel data approach. Sustainability 2017, 9, 1947. [CrossRef]

28. Dvorský, J.; Petráková, Z.; Zapletalíková, E.; Rózsa, Z. Entrepreneurial propensity index of university students. The case study from the Czech Republic, Slovakia and Poland. Oecon. Copernic. 2019. [CrossRef]

29. Ključnikov, A.; Civelek, M.; Čech, P.; Kloudova, J. Entrepreneurial orientation of SMEs? executives in the comparative perspective for Czechia and Turkey. Oecon. Copernic. 2019, 10, 773-795. [CrossRef]

30. Berger, A.N.; Udell, G.F. The economics of small business finance: The roles of private equity and debt markets in the financial growth cycle. J. Bank. Financ. 1998, 22, 613-673. [CrossRef]

31. Cassar, G. The financing of business start-ups. J. Bus. Ventur. 2004, 19, 261-283. [CrossRef]

32. Yang, S.; Ishtiaq, M.; Anwar, M. Enterprise risk management practices and firm performance, the mediating role of competitive advantage and the moderating role of financial literacy. J. Risk Financ. Manag. 2018, 11, 35.

33. Nguyen, T.A.N.; Polách, J.; Vozňáková, I. The role of financial literacy in retirement investment choice. Equilib. Q. J. Econ. Econ. Policy 2019, 14, 569-589. [CrossRef]

34. Hussain, J.; Salia, S.; Karim, A. Is knowledge that powerful? Financial literacy and access to finance. J. Small Bus. Enterp. Dev. 2018. [CrossRef]

35. Rusu, V.D.; Roman, A. Entrepreneurial activity in the EU: An empirical evaluation of its determinants. Sustainability 2017, 9, 1679. [CrossRef]

36. Monitor, G.E. Research papers based on gem data. Glob. Entrep. Monit. 2020, 2, 1056.

37. Baumol, W.J. Entrepreneurial Enterprises, Firms and Large Established Other of the Components Growth Machine. Small Bus. Econ. 2004, 23, 9-21. [CrossRef]

38. Bergmann, H. Entrepreneurial Attitudes and Start-Up Attempts in Ten German Regions. An Empirical Analysis on the Basis of the Theory of Planned Behaviour; University of Cologne: Cologne, Germany, 2002.

39. Coduras, A.; Clemente, J.A.; Ruiz, J. A novel application of fuzzy-set qualitative comparative analysis to GEM data. J. Bus. Res. 2016, 69, 1265-1270. [CrossRef]

40. Sánchez, J.C. University training for entrepreneurial competencies: Its impact on intention of venture creation. Int. Entrep. Manag. J. 2011, 7, 239-254. [CrossRef]

41. Oosterbeek, H.; Van Praag, M.; Ijsselstein, A. The impact of entrepreneurship education on entrepreneurship skills and motivation Eur. Econ. Rev. 2010, 54, 442-454. [CrossRef]

42. Da, Z.; Engelberg, J.; Gao, P. The sum of all FEARS investor sentiment and asset prices. Rev. Financ. Stud. 2015, 28, 1-32. [CrossRef]

43. Krueger, N. The impact of prior entrepreneurial exposure on perceptions of new venture feasibility and desirability. Entrep. Theory Pract. 1993, 18, 5-21. [CrossRef]

44. González-Sánchez, V.M.; Martínez Raya, A.; de los Ríos Sastre, S. An Empirical Study for European Countries: Factors Affecting Economic Growth and Self-Employment by Gender. Sustainability 2020, 12, 9450. [CrossRef]

45. Gavron, R. The Entrepreneurial Society; Institute for Public Policy Research: London, UK, 1998; ISBN 1860300634.

46. Ezebilo, E.E.; Odhuno, F.; Kavan, P. The perceived impact of public sector corruption on economic performance of micro, small, and medium enterprises in a developing country. Economies 2019, 7, 89. [CrossRef]

47. OECD. Progress Report on Financial Education for MSMEs and Potencial Entrepreneurs; OECD: Paris, France, 2015 ; pp. 1-25.

48. OECD. Fostering Markets for SME Finance: Matching Business and Investor Needs; OECD: Paris, France, 2017; pp. 71-95. [CrossRef]

49. OECD. Core Competencies Framework on Financial Literacy for MSMEs; OECD: Paris, France, 2018.

50. Karlan, D.; Valdivia, M. Teaching entrepreneurship: Impact of business training on microfinance clients and institutions. Rev. Econ. Stat. 2011, 93, 510-527. [CrossRef]

51. Wilson, K.E.; Vyakarnam, S.; Volkmann, C.; Mariotti, S.; Rabuzzi, D. Educating the next wave of entrepreneurs: Unlocking entrepreneurial capabilities to meet the global challenges of the 21st century. In Proceedings of the World Economic Forum: A Report of the Global Education Initiative, Geneva, Switzerland, 29 April 2009.

52. OECD/INFE. Toolkit for Measuring Financial Literacy and Financial Inclusion; OECD: Paris, France, 2018.

53. Berman, K.; Knight, J. Financial Intelligence, Revised Edition: A Manager's Guide to Knowing what the Numbers Really Mean; Harvard Business Review Press: Brightton, MA, USA, 2013; ISBN 1422144119.

54. Barte, R. Financial Literacy in Micro-Enterprises: The Case of Cebu Fish Vendors. Philipp. Manag. Rev. 2012, 19, 91-99.

55. Gathungu, J.M.; Sabana, B.M. Entrepreneur Financial Literacy, Financial Access, Transaction Costs and Performance of Microenterprises in Nairobi City County in Kenya. Glob. J. Manag. Bus. Res. 2018.

56. Van Rooij, M.; Lusardi, A.; Alessie, R. Financial literacy and stock market participation. J. Financ. Econ. 2011, 101, 449-472. [CrossRef]

57. Nunoo, J.; Andoh, F.K. Sustaining Small and Medium Enterprises through Financial Service Utilization: Does Financial Literacy Matter? In Proceedings of the Agricultural and Applied Economics Association (AAEA) Conferences-2012 Annual Meeting, Seattle, WA, USA, 12-14 August 2012. 
58. Lusardi, A.; Tufano, P. Debt literacy, financial experiences, and overindebtedness. J. Pension Econ. Financ. 2015, 14, 332-368. [CrossRef]

59. CB Insights. The Top 20 Reasons Startups Fail. Available online: https://www.cbinsights.com/research/startup-failure-reasonstop/ (accessed on 21 April 2021).

60. Wise, S. The impact of financial literacy on new venture survival. Int. J. Bus. Manag. 2013, 8, 30. [CrossRef]

61. Mandell, L.; Klein, L.S. The impact of financial literacy education on subsequent financial behavior. J. Financ. Couns. Plan. 2009, $20,15-24$.

62. Ćumurović, A.; Hyll, W. Financial Literacy and Self-Employment. J. Consum. Aff. 2019, 53, 455-487. [CrossRef]

63. Rigolizzo, M.; Amabile, T. Entrepreneurial creativity: The role of learning processes and work environment supports. Oxf. Handb. Creat. Innov. Entrep. 2015, 61-78. [CrossRef]

64. Abad-Segura, E.; González-Zamar, M.-D. Effects of Financial Education and Financial Literacy on Creative Entrepreneurship: A Worldwide Research. Educ. Sci. 2019, 9, 238. [CrossRef]

65. Jappelli, T.; Padula, M. Investment in financial literacy and saving decisions. J. Bank. Financ. 2013, 37, 2779-2792. [CrossRef]

66. Grant, R.M. Toward a knowledge-based theory of the firm. Strateg. Manag. J. 1996, 17, 109-122. [CrossRef]

67. Davidson, W.N., III; Xie, B.; Xu, W. Market reaction to voluntary announcements of audit committee appointments: The effect of financial expertise. J. Account. Public Policy 2004, 23, 279-293. [CrossRef]

68. Allgood, S.; Walstad, W.B. The effects of perceived and actual financial literacy on financial behaviors. Econ. Inq. 2016, 54, 675-697. [CrossRef]

69. Ye, J.; Kulathunga, K. How does financial literacy promote sustainability in SMEs? A developing country perspective. Sustainability 2019, 11, 2990. [CrossRef]

70. OECD. Overview of the OECD International Network on Financial Education; OECD: Paris, France, 2020.

71. Atkinson, A.; Monticone, C.; Mess, F.A. OECD/INFE International Survey of Adult Financial Literacy Competencies; OECD: Paris, France, 2016; pp. 1-100.

72. OECD. G20/OECD Infe Core Competencies Framework on Financial Literacy for Adults; OECD: Paris, France, 2017; pp. 1-80.

73. Bosma, N.; Hill, S.; Ionescu-Somers, A.; Kelley, D.; Levie, J.; Tarnawa, A. GEM—Global Entrepreneurship Monitor; GEM: London, UK, 2020; ISBN 9781916017825. 